\title{
Can Fortress Europe be feasible?
}

The governments of Germany and France have, in different ways, raised questions about the future of European industry that deserve better answers than they are likely to be given.

JusT over half a year ago, there was general celebration at the reunification of what were then East and West Germany. Nobody then imagined that last week would see the assassination of Detlev Rohwedder, the man who did the thankless job of administering the Treuhand - a kind of holding company for the state-run industrial and commercial enterprises of the east which he converted into a disposal agency. The assassination is personally tragic, of course: why should a public servant (and his family and friends) be required to pay with his life for the difficulty of the job he undertakes? It is also tragic that violence of a kind that has been abroad in West Germany for 30 years should now have appeared in the east. But it is just as alarming that bright hopes of making the eastern parts of Germany prosperous by industrial development have so quickly foundered.

The explanation, as the chairman of the Bundesbank seems not to tire of saying, is elementary. When Bonn decided that Deutschmarks would instantly become the accepted currency in old East Germany, and when wages there had been pegged to rates in the West (without which emigration would have continued and even accelerated), it was inevitable that most eastern enterprises would be unable to compete with their western counterparts. So it has proved. State-owned companies are collapsing before the Treuhand can get them off its hands. Unemployment is rife, and there are crowds marching in city streets. Some guess that half the eastern workforce may be unemployed later in the year. Meanwhile, taxes in Germany have been increased to pay for the subventions and the capital investment necessary to keep the east afloat. Five years from now, there may be a different tale to tell, but five years is a long time for people on the dole.

The developments in France are entirely different and unrelated, but provoke a common question. France, the selfnominated guardian of European technology (with its public interests in aerospace and electronics) is alarmed that two important companies, the computer manufacturer Bull and the electronics and defence manufacturer Thomson, have run into financial trouble, and is planning to help them out with substantial amounts of capital on a scale likely to offend against European rules on unfair competition. France makes no secret of its ambitions: to safeguard in Europe the essential parts of modern industry against the threat of competition from the Far East (not exclusively Japan) and from North America. What the government of France should ask itself is why it is better for the European cause that it should invest in Bull and Thomson than in, say, eastern Germany.
In Europe, France is about as firmly committed as any other member of the European Communities to monetary and political union along lines now being argued out in the committees of the two intergovernmental conferences on these subjects. France must assume that, by about the turn of the century, Europe will be a true common market and even if it does not have a common currency, will have developed a system of national and social mechanisms to ensure that European currencies retain their relative value. And whatever happens, there is no prospect that any single member will think it sensible to get so entirely out of step politically with its fellow-members that these financial arrangements are put at risk. In short, if France were to invest in eastern Germany, it need not fear that at some later stage its investments would be expropriated.

But how would that help to keep advanced technology alive in Europe? This way. If a sixth of Germany is destined to be underemployed while waiting for investment to catch up with the present capital requirements of now-familiar jobs, Europe will be less rich than otherwise. So important social services (education, for example) are needlessly neglected, the European market languishes longer than is necessary and Europe as a whole earns less than it might in the export trade. So, five or ten years from now, Europe will be less able than would otherwise have been the case to invest in the then fashionable technology. Investment in eastern Germany might well, in other words, be at once more profitable and a better defence of European competence than the planned investment in Bull and Thomson - and also less troublesome for Brussels. Who will tell that to the French? $\square$

\section{Australia's talisman}

The Canberra government seems to be playing fast and loose with the Australian National University.

Dом Mintoff, when prime minister of Malta in the 1970s, hit on a simple but effective way of cutting down to size the irritatingly distinguished University of Malta: he used the power of his government's purse to force its merger with the polytechnic institution in the city of Valletta. The predictable result was also quick; true academics quit, would-be academics eagerly filled their shoes, some in Malta cherish the memory of having taken an axe to academic privilege and Malta lacks an outstanding university. In Australia, Bob Hawke's gov- 